\title{
Introduction to the special issue on the Korean financial markets
}

We are pleased to introduce this special issue on the Korean financial markets. This is the first issue entirely dedicated to the Korean financial markets to appear in Managerial Finance and in an academic finance journal printed in North America. The plan that we devote this special issue is largely due to the growing importance of the Korean economy and its capital markets. The Korean financial markets are unique in many respects, including its rapid economic growth with the help of the large business groups or chaebols, severe disruption during the Asian financial crisis in the late 1990s, and the subsequent financial reforms. Korea transformed from being one of the poorest countries in the 1950s to becoming a member of the Organization for Economic Cooperation and Development in 1996. In 2016, Korea was ranked 11th in the world in terms of gross domestic product. However, during the Asian financial crisis in 1997-1998, Korea was one of the hardest hit economies in the region. In the 1990s, Korea implemented a series of financial reforms that opened the security markets to foreign investors and changed the corporate governance structure of firms (Eichengreen et al., 2015). Korea's unique economic development has prompted many researchers to examine the financial policies of Korean firms and their interaction with the financial markets. These studies have made a significant contribution to the finance literature. In addition to a survey article on the Korean corporate finance literature, this issue of Managerial Finance contains six papers on various features of Korean firms and markets. We believe that these seven articles make significant contributions to our understanding of Korean firms and markets.

Lee and Park (2018) survey the Korea-related finance research published in the past 20 years, with a focus on studies on capital structure; capital investments, cost of capital, and capital budgeting methods; equity issuance; corporate governance and the market for corporate control; payout policies; and bank-firm relationship. They also suggest some directions for future research on Korean markets.

Kim et al. (2017) study the changes in the trading volumes of different investors, such as individual investors, domestic institutional investors, and foreign institutional investors, in response to the release of analyst reports. They find that individual investors are the most responsive to analyst reports, followed by domestic institutional investors and foreign institutional investors. They argue that unsophisticated individual investors overreact to the information contained in the analyst reports. Further, they report that domestic institutional investors take advantage of the overreaction by individual investors and make short-term profits.

Woo et al. (2018) investigate the determinants of the bankruptcy risk of Korean audit firms proxied by the costs of debt. They find that the debt costs for Korean audit firms are affected by the client portfolio characteristics as well as financial and organizational characteristics of the audit firms. Specifically, audit firms' costs of debt are found to be positively associated with the characteristics of their client portfolios, such as the incidence (or amount) of lawsuits against the auditor, the proportion of audit clients under surveillance, the ratio of initial audit engagements to all audit engagements, and the proportion of listed companies. The costs of debt are also shown to be affected by the financial and organizational characteristics of audit firms, including the interest coverage ratio, the proportion of receivables to total revenue, firm size, CEO ownership, and existence of a local office.

Jeong and Park (2018) examine the effects of Korean financial institutions' interconnectedness on stock volatility and the quality of price discovery. They report a positive association between 
the connectedness of financial institutions and the volatility of stock prices and a negative relationship between connectedness and the quality of price discovery.

Chung and Kang (2018) forecast the growth of the Korean venture capital industry using the Bass (1969) model and suggest a fundraising schedule that supports the forecasted growth. They estimate the innovation $(p)$ and imitation $(q)$ parameters of the Bass model for the Korean venture capital industry and compare these estimates with those for the USA. They show that the Korean venture industry has a larger $p$ and a smaller $q$ than the USA, and argue that the Korean Government's investment in the venture capital industry leads to a larger $p$, while weak private sector activities lead to a smaller $q$. They also show that the annual new investment of the Korean venture capital industry is expected to grow at a rate of 5-7 percent for the next five years and to peak around the year 2030.

Shaub (2018) investigates the performance of the American depository receipts (ADRs) listed by Korean firms, and finds no statistical evidence that Koran ADRs perform differently from the S\&P 500 index. Segmentation of the sample by the venues of listing shows that the performance of the NYSE-listed Korean ADRs is not statistically different from the S\&P 500 index, although the NASDAQ-listed Korean ADRs underperform the US market index. However, the results should be taken with caution due to a small sample size used in the study (12 ADRs with eight listed on the NYSE and four listed on the NASDAQ).

In this issue, we also explore corporate finance in an international setting including data for Korea. Park et al. (2018) examine the effects of controlling shareholders' ownership on the change in investment propensity and financial constraints of firms in 22 countries. They report that the high cash-flow rights of the controlling shareholders and a large deviation between the control rights and cash-flow rights of the controlling shareholders reduce their propensity to overinvest, and thus lower firms' financial constraints.

We want to conclude this preview of the special issue by expressing our appreciation to the authors of these articles. We thank them for submitting their valuable and insightful studies for inclusion in this special issue of Managerial Finance on Korean firms and markets. We would like to thank Valerie Robillard, the Publisher, for her advice and support during the editing process. We also want to thank Don Johnson, the Editor, for his dedicated editorial help and for giving us this opportunity to serve as guest editors for this issue.

Hongbok Lee College of Business and Technology, Western Illinois University, Macomb, Illinois, USA, and

Kwangwoo Park College of Business, Korea Advanced Institute of Science and Technology, Seoul, Korea

\section{References}

Bass, F.M. (1969), “A new product growth for model consumer durables”, Management Science, Vol. 15 No. 5, pp. 215-227.

Chung, H.J. and Kang, M.Y. (2018), “Assessing venture capital industry growth in Korea”, Managerial Finance, Vol. 44 No. 1, pp. 74-85.

Eichengreen, B., Lim, W., Park, Y.C. and Perkins, D.H. (2015), The Korean Economy, Harvard University Asia Center, Harvard University Press, Cambridge, MA.

Jeong, D.J. and Park, S. (2018), "The more connected, the better? Impact of connectedness on volatility and price discovery in the Korean financial sector", Managerial Finance, Vol. 44 No. 1, pp. 45-73. 
$\mathrm{MF}$

44,1

4
Kim, K.S., Park, J. and Park, Y.W. (2017), "Differential informativeness of analyst reports by investor types: evidence from the Korean stock market”, Managerial Finance, Vol. 43 No. 5, pp. 567-594.

Lee, H. and Park, K. (2018), "Advances in the corporate finance literature: a survey of recent studies on Korea”, Managerial Finance, Vol. 44 No. 1, pp. 5-25.

Park, J.H., Park, K. and Ratti, R.A. (2018), "Controlling shareholders and financial constraints around the world", Managerial Finance, Vol. 44 No. 1, pp. 92-108.

Shaub, M. (2018), "A note on the long-term performance of Korean ADRs", Managerial Finance, Vol. 44 No. 1, pp. 86-91.

Woo, Y.-S., Kang, M. and Lee, H.-Y. (2018), "The cost of debt and the characteristics of audit firms", Managerial Finance, Vol. 44 No. 1, pp. 26-44. 